\title{
ANALYSIS AND EVALUATION OF IMPLEMENTATION OF UNDERGRADUATE NURSING CURRICULLUM FOR FAMILY NURSING IN WEST JAWA
}

\author{
(Analisis Dan Evaluasi Pelaksanaan Kurikulum Sarjana Keperawatan Untuk \\ Keperawatan Keluarga Di Jawa Barat)
}

\author{
Neti Juniarti, Sheizi Prista Sari, Desy Indra Yani \\ Faculty of Nursing, Universitas Padjadjaran, Jl. Raya Bandung-Sumedang Km 21, Gedung L1 Lt.2, \\ Kampus Universitas Padjadjaran Jatinangor, Telp/fax : 022-7795596 \\ E-Mail: juni0011@flinders.edu.au
}

\begin{abstract}
ABSTRAK
Pendahuluan: Perawat merupakan tulang punggung dari sistem kesehatan, menjadi penyedia utama layanan kesehatan primer sebagai mereka terdiri $60-80 \%$ dari total tenaga kerja kesehatan, dan memberikan $90 \%$ dari semua layanan perawatan kesehatan di arena kesehatan primer. Penelitian ini bertujuan untuk mengevaluasi kesesuaian keperawatan keluarga dan kurikulum keperawatan kesehatan masyarakat dengan standar internasional dan kebutuhan nasional untuk pendidikan keperawatan sarjana di Jawa Barat. Metode: Penelitian ini menggunakan desain penelitian evaluasi dengan menggunakan kerangka BEKA sebagai alat untuk melakukan analisis kurikulum yang termasuk Benchmarking, Membuktikan, Mengetahui, dan Menerapkan tahap. Standar internasional kompetensi keperawatan keluarga dan perawat kesehatan masyarakat, panduan belajar kursus dan sampel dari laporan siswa dikumpulkan dan dianalisis menggunakan analisis isi. Selain peserta dari enam sekolah keperawatan diwawancarai untuk mengidentifikasi penerapan kurikulum. Hasil: Hasil penelitian menunjukkan bahwa beberapa kompetensi yang digariskan dalam buku ini tentu saja tidak sesuai dengan standar internasional keperawatan keluarga dari Asosiasi Perawatan Keluarga Internasional. Empat kerangka dimensi keperawatan keluarga dan kurikulum keperawatan kesehatan masyarakat yang diusulkan untuk meningkatkan keselarasan antara standar internasional serta lokal dan pemerintah perlu untuk keperawatan keluarga dan perawat kesehatan masyarakat kurikulum. Diskusi: Sekolah keperawatan dapat menerapkan kerangka ini sebagai pedoman untuk mengembangkan rencana pembelajaran mereka sendiri berdasarkan standar internasional, nasional, lokal dan kebutuhan kelembagaan.
\end{abstract}

Kata kunci: analisis kurikulum, evaluasi, keperawatan keluarga, keperawatan kesehatan masyarakat

\begin{abstract}
Introduction: Nurses are the backbone of the healthcare system, being the key providers of primary healthcare as they comprise $60-80 \%$ of the total health workforce, and provide $90 \%$ of all heath care services in the primary healthcare arena. This study aimed to evaluate the concordance of family nursing and community health nursing curriculum with international standards and national needs for undergraduate nursing education in West Java. Methods: This study used evaluation research design using BEKA framework as a tool to perform curriculum analysis which included Benchmarking, Evidencing, Knowing, and Applying stages. The international standards competency for family nursing and community health nursing, course study guide and samples of students reports were collected and analysed using content analysis. In addition participants from six nursing schools were interviewed to identify application of the curriculums. Results: The results show that some of the competencies outlined in the course study guide were not aligned with international standards of family nursing from International Family Nursing Association. Four dimensional framework of family nursing and community health nursing curriculums were proposed to improve the alignment between international standards as well as local and government needs for family nursing and community health nursing curriculums. Discussion: School of nursing can apply this framework as guidance to develop their own learning plans based on international standards, national, local and institutional needs.
\end{abstract}

Keywords: curriculum analysis, evaluation, family nursing, community health nursing

\section{INTRODUCTION}

Nurses are the backbone of the healthcare system, being the key providers of primary healthcare (Kurtzman \& Kizer 2005) as nurses comprise $60-80 \%$ of the total health workforce, and provide $90 \%$ of all heath care services in the primary health care (WHO 2008). This significant presence has enormous potential for improving the health status of people in the community because nurses can have a positive impact on increasing the self-reliance of people in the community and empowering people to maintain their health through education and disease prevention, which then reduces 
morbidity and hospitalisation (Kurtzman \& Kizer 2005; Swiadek 2009).

In addition, Indonesian middle range plan development has declared a healthy family program and primary health care through health promotion and disease prevention (Kementerian Kesehatan RI 2015). Therefore, nursing education institution need to have orientation towards family health and the community so that it can contribute to the improvement of community independence and empowerment through health education dan disease prevention, which in the end can help to reduce morbidity and hospitalisation (Swiadek 2009). Competencies in family nursing are obtained through educational process in class as well as in the practice settings (Gaberson \& Oermann 2010).

In Indonesia, healthcare services in the community setting are provided through community health centres or the Puskesmas as a primary level healthcare delivery facility According to Indonesian Ministry of Health Regulation number 75 year 2014, the Puskesmas is responsible for the coordination and integration of all health programs as well as a placement site for students. Unfortunately, the activities of Indonesian community nurses has not given a leverage to improve the health of family and the community, although nurses comprised of $60-80 \%$ of total health workforce (WHO 2008), contribution of community health nurses has not been seen in the health syste. Most of Indonesia nurses did not perform family nursing and community nursing services (DIKTI 2011). Survey also showed that $48 \%$ nurses said that their competencies were not as good as expected, meanwhile $36.2 \%$ people in the community stated that competencies of nurses were not as their expected (DIKTI 2011). This shows that community health nursing and family nursing education has not produced desirable outcomes for the community. Therefore, a research to analyse and evaluate the implementation of family nursing curriculum is needed so that nursing education institution can improve their curriculum to contribute to the healthy family program in Indonesia.

\section{AIM AND OBJECTIVES}

Aim

The aim of this study was to evaluate the alignment of family nursing curriculum with the standards, national and local needs related to family health in West Java Province.

\section{Objectives}

The objectives of this study were:

1. To analyse the alignment of family nursing learning plan with the standards, national dan local needs

2. To compare the strengths and weaknesses of various nursing diagnoses methods.

\section{URGENCY OF THE STUDY}

Core curriculum of bachelor nursing program in Indonesia required all nursing education institution to include family nursing in their academic and profession curriculum (AIPNI 2015). Through nursing education, With nursing education program, the government expects that the improvement of level of education can contribute to the improvement of nursing practice in hospitals and the Puskesmas; however, the impacts of nursing education on the improvement of nursing practice in Indonesia are relatively low (Aitken 2008). This is due to a gap between $\mathrm{CHN}$ practice and education in Indonesia which lead to lack of a $\mathrm{CHN}$ educational model as the site of community placement for nursing students in Indonesia (Samba 2012). Therefore, continuous evaluation of learning outcomes, process, and the content of family nursing curriculum is very important (Hall, 2014).

As the changes of core curriculum from competency-based to Indonesian National Qualification Framework (KKNI) were happening in 2015, as well as the changes in the government vision and mission regarding health, then it is important to conduct analysis and evaluation of family nursing curriculum. In the AINEC core curriculum 2015, it was stated that Family Nursing topic is 4 credit semesters (SKS) which consist of 3 SKS theory dan 1 SKS for practicum (AIPNI 2016). Up to now, there has not been any publication 
related to evaluation of family nursing curriculum in Indonesia. With the changes in the curriculum, the analysis and evaluaton of family nursing curriculum can help nursing education institutions to adjust and improve the implementation of family nursing education so that it can be aligned with national goals. Thus, the nursing education institution can make contribution towards health development of people in Indonesia. Curriculum evaluation is needed to help decision-making process in nursing education. Higher educations around the globe have been recognised the importance of outcome-basd education so that people in the community prefer outcomes than achievement of learning objective. Therefore, nursing education is also expected to produce a positive outcomes for the people and their environment (Hall 2014).

\section{LITERATURE REVIEW}

\section{Family Nursing Curriculum}

Nursing curriculum must be relevant and responsive towards the reality in practice setting so that analysis and evaluation of learning objectiives, process and contents of the curriculum is important (Dignam et al., 2012). Curriculum is a set of planning tools and regulation regarding the graduate learning outcomes, topics, process, and assessment that is used as guidance in the operation of higher education (Permenristekdikti No. 44 tahun 2015). Nursing education institutions need to aligned their family nursing curriculum to the standards, as well as national and local needs so that they can produce professional nurses who can strengthen the health system in the country (World Health Organization 2009).

The needs of community health needs consist of four major aspects which are clinical care, health maintenance, support for healthy living, and wellbeing and other support including comprehensive community health nursing in all health risks and problems (World Health Organization 2010). In developing countries, community nursing services are including five level which are individual, families, groups, and the communities; health services provision by professionals, and wellbeing and support that are given by other institution or organisasion in the community.

Eventhough community health nursing intervention are including individuals and families, family nursing is a specific discipline in nursing. Family nursing is defined as a process of health services provision that is needed by the families in the scope of nursing practice. Family nursing can be done in the family as context, family as system or family as part of community components (Kaakinen et al., 2014). The roles of family nursing include: 1) health educator, 2) coordinator, collaborator, and connector, 3) healthcare provider and technical experts, 4) family advocate, 5) consultant, 6) counsellor, 7) case finder and epidemiologist, 8) environmental health, 9) case manager, 10) researcher, 11) role model, 12) clarificator dan interpreter, 13) surrogate for family members who could not be with the client (Kaakinen et al., 2014). Family nursing uses nursing process as the framework which consists of assessment, planning, intervention, and evaluation (Riedford 2011).

\section{Analysis and Evaluation of Curriculum}

Curriculum evaluation is assessment activities regarding the nature, impact, and benefit of curriculum through systematic data collection, analysis, and interpretation of data in order to make decision. The purpose of this process is to do deep analysis in some or whole parts of the curriculum which considers the curriculum users (Hall 2014). Various technique can be used to evaluate the curriculum such as using questionnaire and interviews as valuable techniques to collect comprehensive information that can help the curriculum evaluation (Hall 2014).

Conceptual mapping framework by Matveev et al. (2010) from the USA can be applied as a model for analysis and evaluation of curriculum. This model uses five steps for curriculum mapping, namely topics, syllabus, instructional activities, dan learning assessment. Reid (2005) suggested to consider type of curriculum in the evaluation, for example null, hidden or undesirable currilum, and explicit and implicit curriculum. The null curriculum is not hidden but it is deleted purposively so that there are some 
there are some missing parts as the content is removed purposively. Hidden curriculum is happened because of influences of other factors that creates changes in students' attitude, perception, and behaviour including unwritten law for survival.

Hall (2014) conducted curriculum analysis and evaluation based using four steps which are benchmarking, evidencing, knowing, applying. Benchmarking is a process to identify documents which will serve as the standards or criteria. Curriculum benchmarking can use international standards as well as policies and regulations of government or other stakeholders such as users, consumers, professional organisations, and other nursing education institutions (Harris et al., 2010). Evidencing is a process to check the curriculum with the standards. To do this, all the course documents are considered in details to identify the written curriculum that have been implemented as well as to identify the hidden or null curriculum. Evidence for the learning objectives, content, learning sources, and assessment are mapped to identify its alignment with the standard documents (Hall, 2014). Knowing in the curriculum evaluation is a deeper process of analysis to identify and understand lecturers' understanding about what are taught and why they are taught to students (Hall, 2014). The last stage is application stage to examine how students understand the knowledge and apply what they have learned by asking the students' understanding and application of the knowledge. Using the four stages for curriculum analysis and evaluation, lecturers can obtain a complete picture that can help in decision making in nursing education institution (Hall, 2014).

\section{METHODS}

This study used evaluation research design. Evaluation research is a type of study that aims to asses and improve the effectiveness of activities through systematic and careful research process and analysis (Mertens \& Wilson 2012).
Variables in this study are:

1. Alignment of learning plan for family nursing with the standards

2. Alignment of family nursing process with the standards

Data in this study are including documents related to family nursing topic, lecturers who teach the family nursing topic, and students who have learned the familly nursing from nursing education institutions in West Java Province. Participants were recruited by sending an email invitation to the lecturers of education institutions. A total of 6 nursing education institution in West Java were willing to participate. Documents that were collected including learning plan or sylabus, other supporting documents such as module and students' guidebook, and family nursing care plan or students' report. Interview participants were including lecturers who teach family nursing topic and students. Total of 6 lecturers and 18 students were interviewed whichranged ranged from 30 to 45 minutes. All researchers interviewed participants.

Data collection consisted four stages which are:

a. Benchmarking: data for benchmarking were collected from International Family Nursing Association Competencies for Generalist, Government Program in family health, Indonesian National Qualification Frame, West Java Development Plan, NANDAInternational, and International Classification of Nursing Practice. These benchmark documents will be mapped to help the data analysis.

b. Evidencing: collecting documents that consisted of 6 learning plan or syllabus, 24 family nursing reports from students. This document is needed to evaluate the planning and implementation of family nursing curriculum as well as impact or outcomes of the nursing process that were documented in the documents.

c. Knowing: data collection in this stage were conducted through interviewing lecturers to examine what lecturers' view about missing curriculum, resources that influence the 
Analysis and Evaluation of Implementation (Neti Juniarti, Sheizi Prista S., Desy Indra Y.)

\begin{tabular}{|c|c|c|c|c|c|c|c|c|c|c|c|c|}
\hline 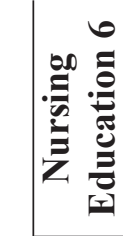 & & 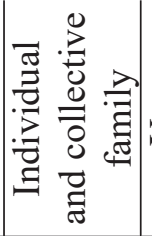 & 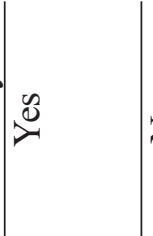 & $\stackrel{\circ}{z}$ & $\stackrel{\circ}{z}$ & $\stackrel{\circ}{z}$ & & $\nu^{\infty}$ & $\stackrel{\infty}{\infty}$ & $\stackrel{\infty}{\nu}$ & $\stackrel{\infty}{\infty}$ & $\overbrace{}^{\infty}$ \\
\hline 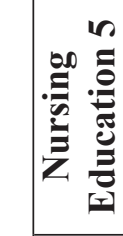 & & 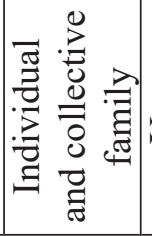 & 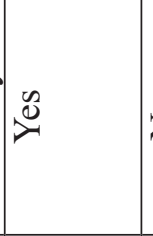 & $\stackrel{\circ}{z}$ & 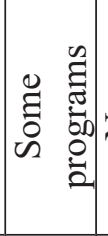 & z & & $\stackrel{\infty}{\infty}$ & $i^{\infty}$ & $\stackrel{\infty}{2}$ & $i^{\infty}$ & $\stackrel{\infty}{\infty}$ \\
\hline 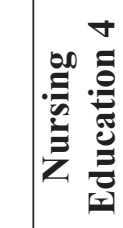 & & 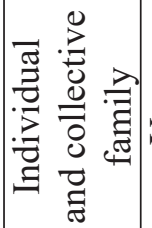 & 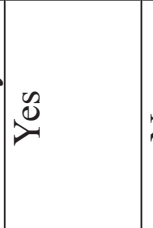 & $\stackrel{\circ}{z}$ & 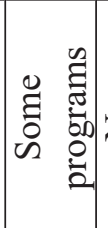 & $\stackrel{\circ}{z}$ & & $\stackrel{0}{\nu}$ & $\sum^{\infty}$ & $\stackrel{0}{\nu}$ & $\sum^{\infty}$ & $\sum^{\infty}$ \\
\hline 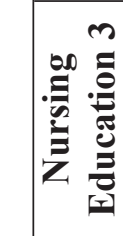 & & 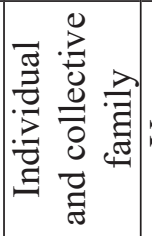 & 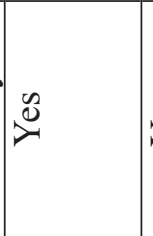 & $\stackrel{\infty}{\infty}$ & 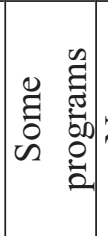 & $\stackrel{\circ}{z}$ & & $\stackrel{0}{\nu}$ & $\stackrel{\Delta}{\infty}$ & $\stackrel{0}{\nu}$ & $\stackrel{\infty}{\infty}$ & $\stackrel{\Delta}{\infty}$ \\
\hline 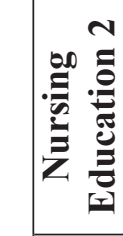 & & 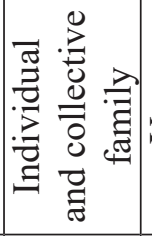 & 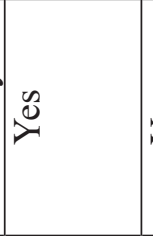 & $\triangleq$ & $\stackrel{\circ}{z}$ & $\stackrel{\circ}{z}$ & & $\nu^{\infty}$ & $\stackrel{\infty}{\infty}$ & $\stackrel{\infty}{\infty}$ & $\stackrel{\infty}{\infty}$ & $\stackrel{\circ}{z}$ \\
\hline 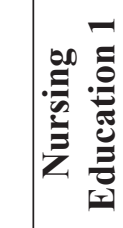 & & 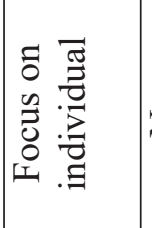 & $\stackrel{\circ}{Z}$ & Z & $\stackrel{\circ}{Z}$ & $\stackrel{\circ}{Z}$ & & $\stackrel{0}{\nu}$ & $\nu_{\nu}^{\infty}$ & $\nu_{\nu}^{\infty}$ & $\sum^{\infty}$ & $\stackrel{\circ}{z}$ \\
\hline 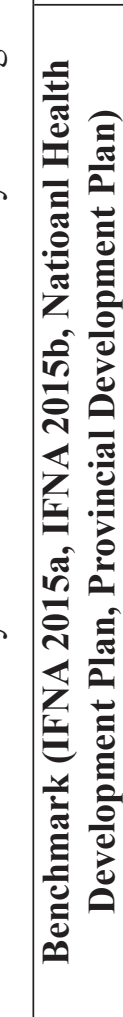 & 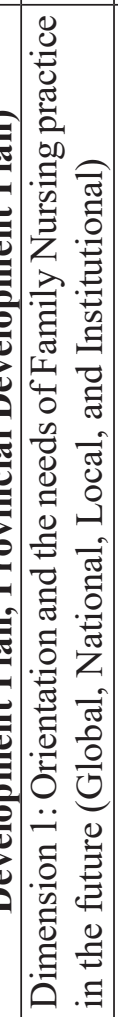 & 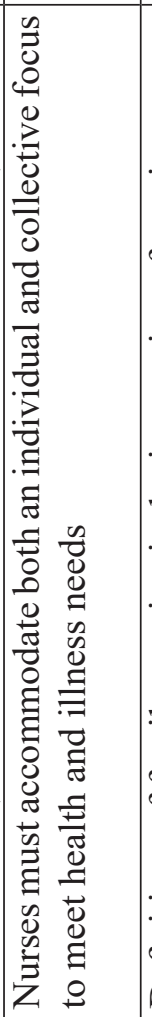 & 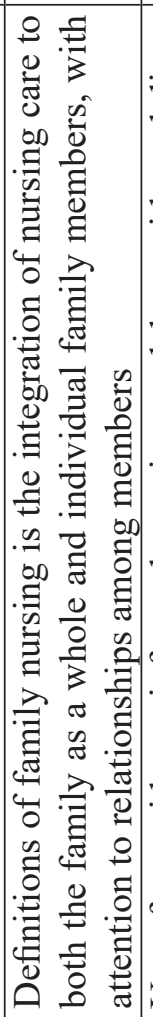 & 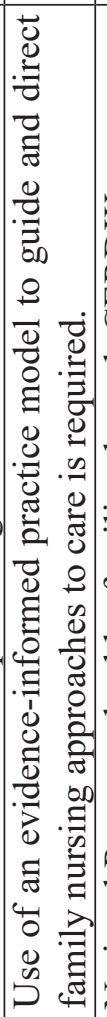 & 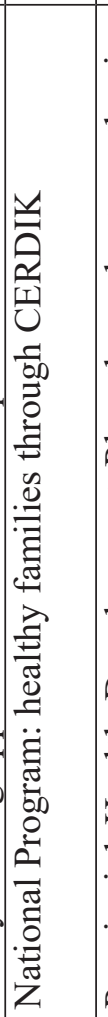 & 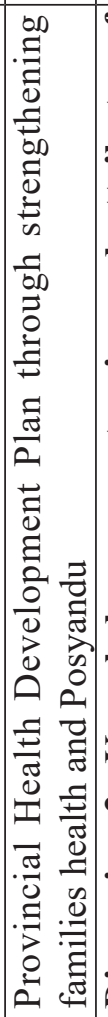 & 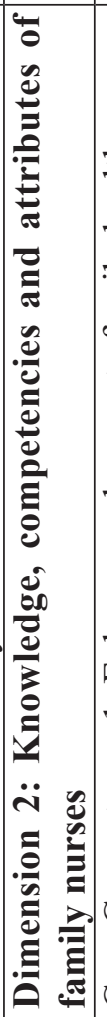 & 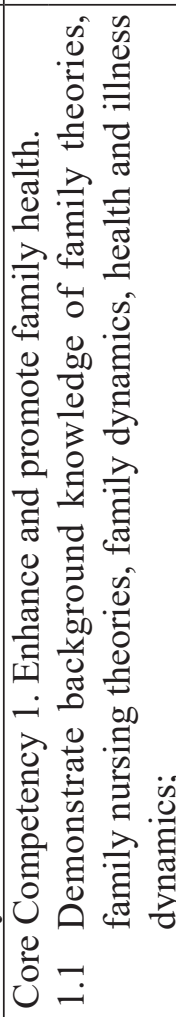 & 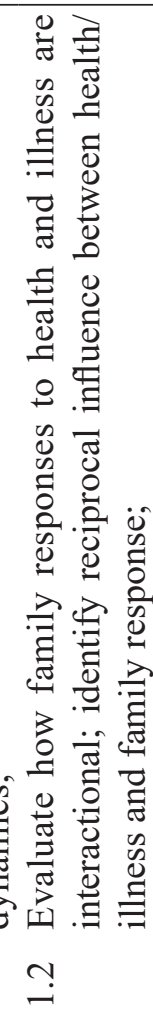 & 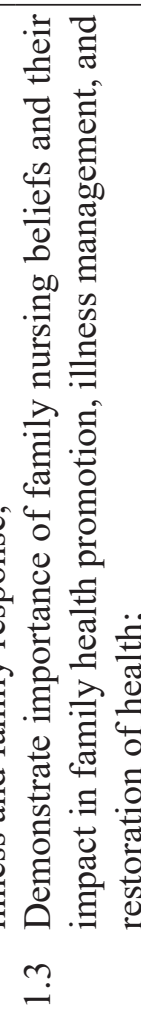 & 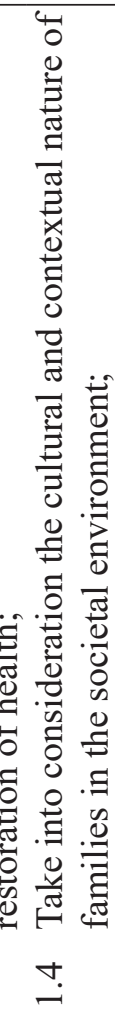 & 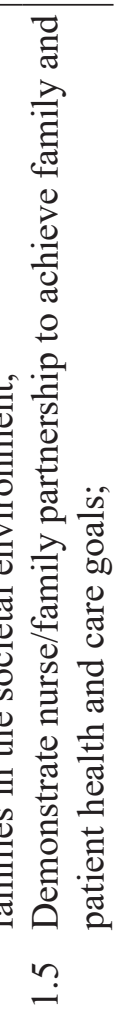 \\
\hline
\end{tabular}


Jurnal INJEC Vol. 1 No. 2 Desember 2016: 103-114

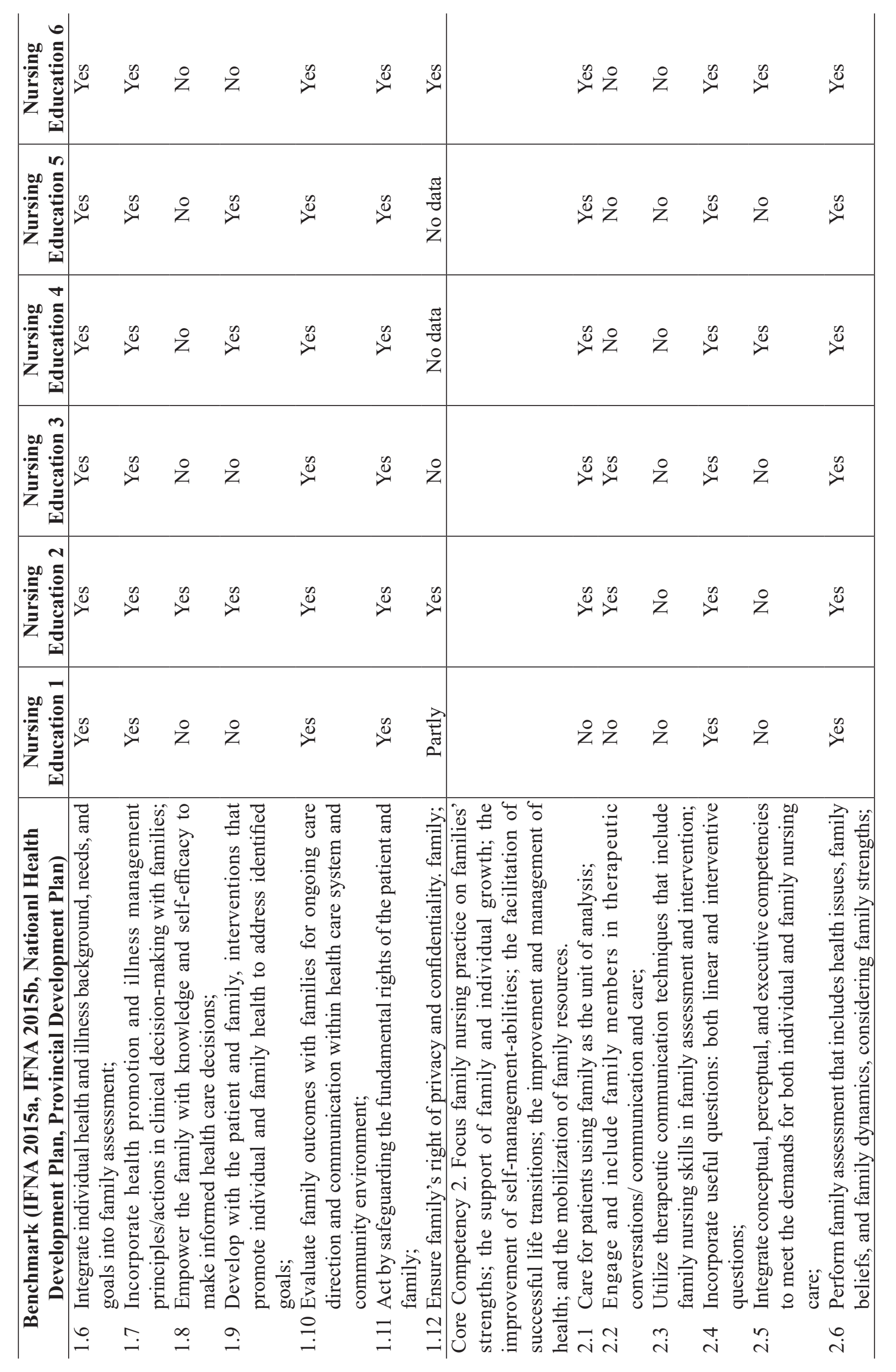


Analysis and Evaluation of Implementation (Neti Juniarti, Sheizi Prista S., Desy Indra Y.)

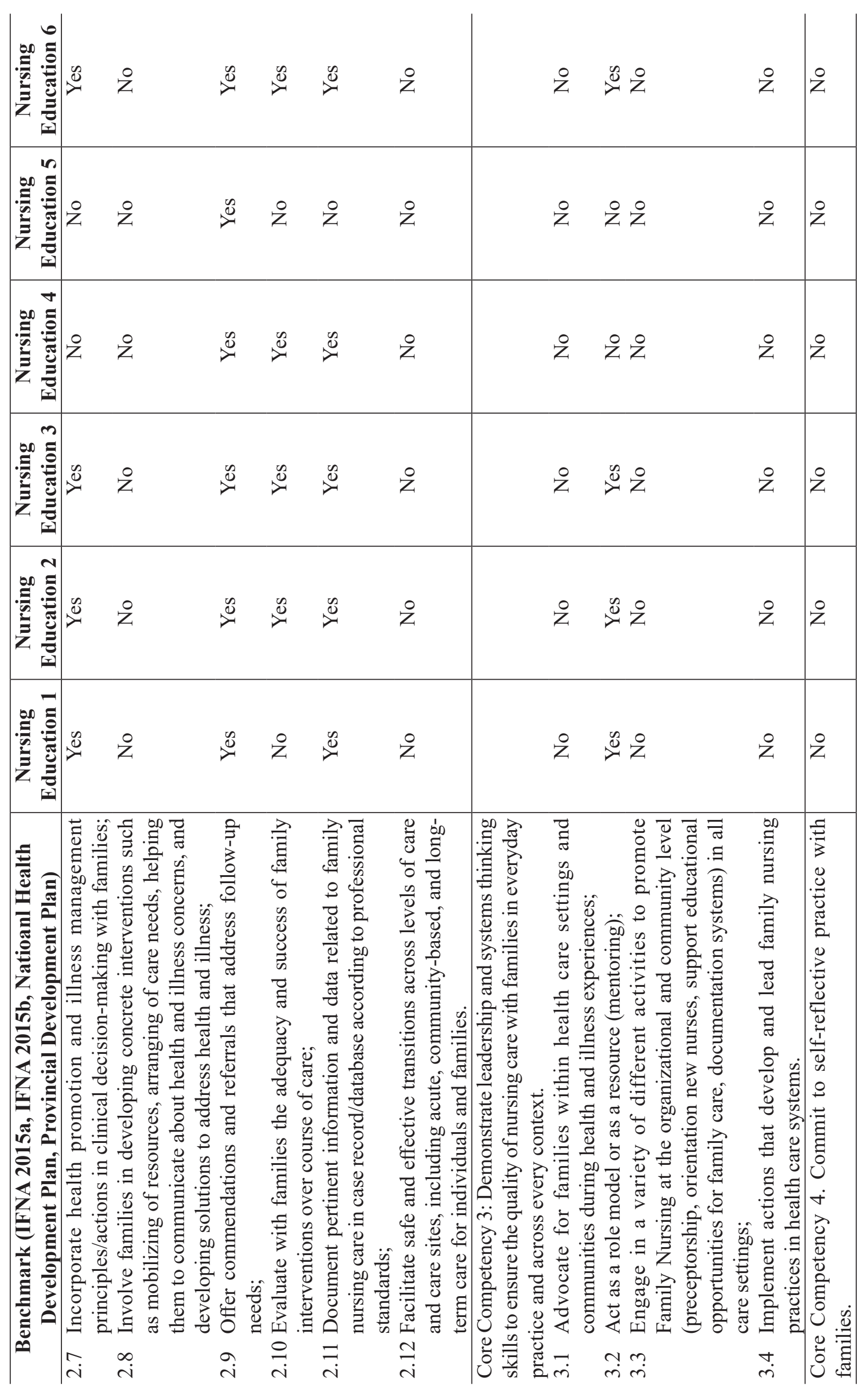


Jurnal INJEC Vol. 1 No. 2 Desember 2016: 103-114

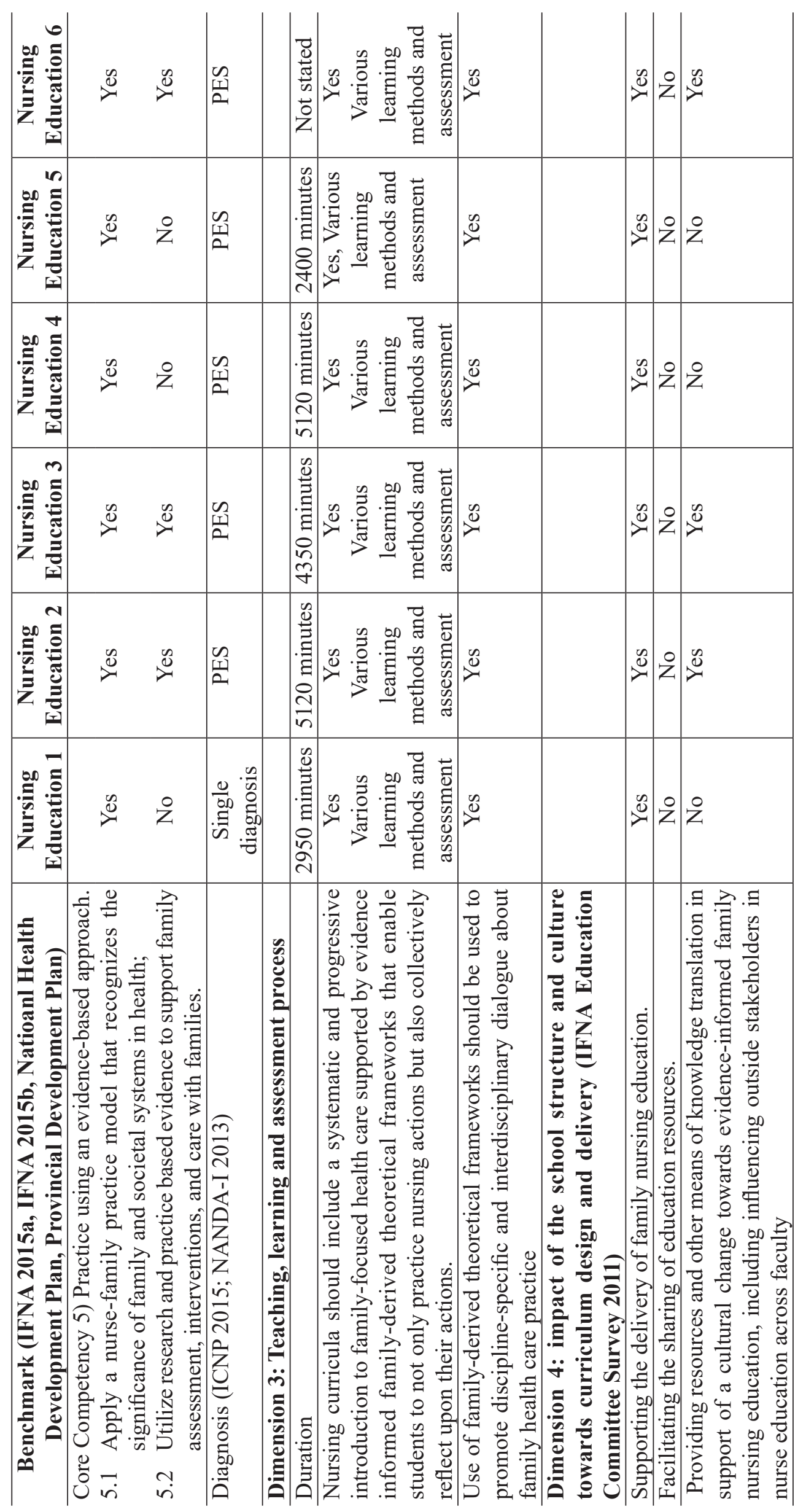


implementation, and what actually being taught to students and why these were taught.

d. Applying: data collection in this phase were including interviews to students to explore their understanding about family nursing and the application of the family nursing in the real setting.

The data were analysed using content analysis, thematic Analysis (Braun and Clark 2006) and cross-case synthesis.

This study was approved by Health Research Ethic Committee Faculty of Medicine Universitas No. 706/UN6.C1.3.2/ $\mathrm{KEPPK} / \mathrm{PN} / 2016$ to ensure that this study was conducted in ethical manners by respecting the participants right, providing beneficence and justice for the participants.

\section{RESULTS}

The results of four stages analysis (benchmarking, evidencing, knowing and application) were summarised in Table 1 as follow. Based on these analysis, the family nursing curriculum needs to be improve in nursing education institutions particularly to strengthen the competencies of demonstrating leadership and system thinking, reflective practice, and applying evidence-informed practice. In addition, the curriculum also needs to incorporate national program and provincial health programs into the curriculum. In terms of nursing diagnosis, nursing education institutions need to apply a current and standardise nursing diagnosis using seven axes as outlined by NANDA-International and International Classification of Nursing Practice from International Council of Nurses.

\section{DISCUSSION}

Nursing curriculum must be relevant and responsive towards the reality in practice setting so that analysis and evaluation of learning objectiives, process and contents of the curriculum is important (Dignam et al. 2012). Curriculum evaluation is assessment activities regarding the nature, impact, and benefit of curriculum through systematic data collection, analysis, and interpretation of data in order to make decision. The purpose of this process is to do deep analysis in some or whole parts of the curriculum which considers the curriculum users (Hall 2014). This study has showen that the duration of family nursing topic were varied between institutions. The duration rangerd from 1600 minutes (equal to 27 hours) to 5120 minuters (equal to 87 hours). World Health Organization (2010) has given an example of 80 hours of community nursing curriculum for bachelor degree. Since the duration were varied, then the competencies being taught were varied among nursing education institutions aswell. The benchmarking and evidencing results showed that the core curriculum for family nursing needs to be improved particularly in demonstrating leadership and system thinking, performing reflective practice, and applying evidence-informed practice. In addition, nursing education institution also need to incorporate national program and provincial health development program in the family nursing area. Family nursing can be used in individuals using family as context or family as system or family as component of the community (Kaakinen et al., 2014).

Family nursing need to use the family process as the frameworks to perform assessment, planning, intervention, and evaluation (Riedford 2011). For the nursing diagnosis, nursing education institutions need to reference the current and up date diagnosis system as outlined by NANDA International or International Classification of Nursing Practice (ICN 2015). The results in this study showed that there is a single diagnoses phenomena being implemented in bachelor degree. Based on the benchmarking and literature review of family nursing, the term single diagnosis is not recognised. According to NANDA International the components of a diagnosis consist of diagnosis label, definition, defining characteristic, risk factors and related factors (NANDA-I 2016). Therefore, lecturers need to use international standardised nursing diagnosis to prevent confusion among students.

According to NANDA-I (2013) dan ICN (2015), Nursing Diagnosis a "clinical judgment 


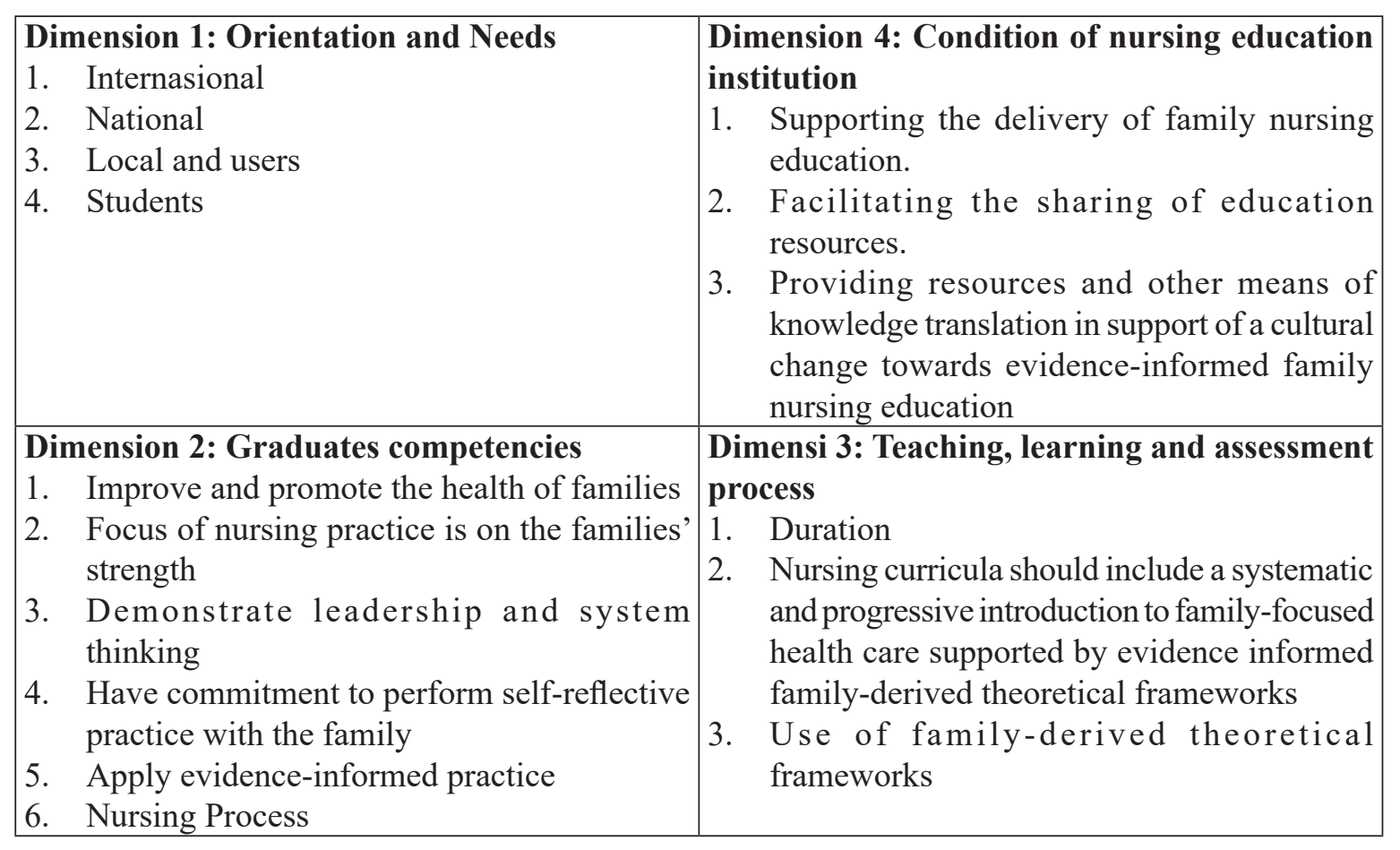

Figure 1 Framework of Analysis, Evaluation dan Development of Family Nursing Curriculum

concerning a human response to health conditions/life processes, or a vulnerability for that response, by an individual, family, group or community. A nursing diagnosis provides the basis for selection of nursing interventions to achieve outcomes for which the nurse has accountability" (p. 1). There are three types of nursing diagnosis, the first is problem-focused nursing diagnosis, which is a clinical judgment concerning an undesirable human response to health conditions/life processes that exists in an individual, family, group, or community. In order to make a problem-focused diagnosis, the following must be present: defining characteristics (manifestations, signs, and symptoms) that cluster in patterns of related cues or inferences. Related factors (etiological factors) that are related to, contribute to, or antecedent to the diagnostic focus are also required. The second is health promotion nursing diagnosis, which is a clinical judgment concerning motivation and desire to increase well-being and to actualize human health potential. These responses are expressed by a readiness to enhance specific health behaviors, and can be used in any health state. Health promotion responses may exist in an individual, family, group, or community. In order to make a health-promotion diagnosis, the following must be present: defining characteristics which begin with the phrase, "Expresses desire to enhance...". The third one is risk nursing diagnosis which is a clinical judgment concerning the vulnerability of an individual, family, group, or community for developing an undesirable human response to health conditions/life processes. In order to make a risk-focused diagnosis, the following must be present: supported by risk factors that contribute to increased vulnerability.

There are seven axis in the international standards reference model for a nursing diagnosis. An axis is operationally defined as a dimension of the human response that is considered in the diagnostic process. These seven axes (NANDA-I 2016) are:

Axis 1: the diagnostic focus

Axis 2: subject of the diagnosis (individual, caregiver, family, group, community)

Axis 3: judgment (impaired, ineffective, etc.)

Axis 4: location (bladder, auditory, cerebral, etc.)

Axis 5: age (infant, child, adult, etc.)

Axis 6: time (chronic, acute, intermittent)

Axis 7: status of the diagnosis (problemfocused, risk, health promotion). 
The axes are represented in the labels of the nursing diagnoses through their values. In some cases, they are named explicitly, such as with the diagnoses, Ineffective Community Coping and Compromised Family Coping, in which the subject of the diagnosis (in the first instance "community" and in the second instance "family") is named using the two values "community" and "family" taken from Axis 2 (subject of the diagnosis). "Ineffective" and "compromised" are two of the values contained in Axis 3 (judgment) (NANDA-I 2016).

Based on results of this study, authors proposed a four dimensional framework that can help lecturers to analyse and develop family nursing curriculum. This framework is presented in figure 1 as follow.

This proposed framework was developed using Lee et al. (2012) four dimensional curriculum development which combined with the benchmarking results. This framework can be used to evaluate, analyse, and develop curriculum for family nursing in nursing education institution. The contents of this curriculum are not exhaustive as these needs to be re-evaluated regularly to see whether they are still relevant with the current situation. This study has found that most of nursing education institutions have not included provincial and national policy in the family nursing curriculum. As the results, the nursing graduates are not work ready when they are work in Puskesmas settings (community health centers) to perform the national program "Healthy Family". In order to overcome this issue, family nursing lecturers can use Figure 1 as a framework to update the content of their curriculum in a regular basis.

\section{CONCLUSION AND RECOMMENDATION}

\section{Conclusion}

It can be concluded that competencies for family nursing curriculum that has been implemented in West Java were varied due to variation in the duration of the topic. There are also needs to be improved particularly in the three areas of system thinking, reflective practice, and evidence-informed practice, as well as national and provincial development programs. Thus, the nursing graduates would be ready to fulfil the national and provincial demands while also aligned with international standards.

\section{Recommendation}

Family nursing curriculum needs to incorporate national and provincial health programs, The core curriculum for family nursing needs to add leadership and system thinking, reflective practice and evidenceinformed practice, Nursing diagnosis needs to use the current reference from ICNP, Nursing education institutions needs to support lecturers to perform analysis and evaluation of family nursing using the proposed framework.

\section{REFERENCE}

AIPNI. 2016. Kurikulum Inti Pendidikan Ners Indonesia, Asosiasi Institusi Pendidikan Ners Indonesia Jakarta.

Braun, V \& Clarke, V. 2006. 'Using thematic analysis in psychology', Qualitative Research in Psychology, vol. 3, no. 2, pp. $77-101$.

BPDPJ Barat. 2016. Arah Kebijakan Pembangunan Provinsi Jawa Barat 2016, by Badan Perencanaan Daerah Propinsi Jawa Barat.

Dignam, D, Duffield, C, Stasa, H, Gray, J, Jackson, D \& Daly, JM. 2012. 'Management and leadership in nursing: an Australian educational perspective', Journal of Nursing Management, vol. 20, pp. 65-71.

DIKTI. 2011. Potret Ketersediaan dan Kebutuhan Tenaga Perawat, DIKTI, Jakarta.

Gaberson, K \& Oermann, M. 2010. Clinical Teaching Strategies in Nursing, Springer Publishing Company, New York.

Hall, CE. 2014. 'Toward a model of curriculum analysis and evaluation-Beka: A case study from Australia', Nurse Education Today, vol. 34, no. 3, pp. 343-8.

Harris, L., Driscoll, P., Lewis, M., Matthews, L., Russell, C., Cumming, S. 2010. Implementing curriculum evaluation: case study of a generic undergraduate 
degree in health sciences. Assessment \& Evaluation in Higher Education 35 (4), 477-490.

International Council of Nurses 2008. Guidelines for ICNP ${ }^{\circledR}$ Catalogue Development, International Council of Nurses, Geneva.

_- 2015. Community Nursing, International Council of Nurses, Geneva.

International Family Nursing Association. 2013, Position Statement on Pre-Licensure Family Nursing Education International Family Nursing Association, Minnesota, USA.

2015. Position Statement on Generalist Competencies for Family Nursing Practice International Family Nursing Association, Minnesota, USA.

Kaakinen, JR, Coehlo, DP, Steele, R, Tabacco, A \& Hanson, SMH. 2014. Family health care nursing: Theory, practice, and research, FA Davis.

Kementerian Kesehatan RI. 2015. Rencana Pembangunan Jangka Menengah dalam Bidang Kesehatan, by Kementerian Kesehatan RI, Kementerian Kesehatan RI.

Lee, A, Steketee, C, Rogers, G \& Moran, M. 2013. 'Towards a theoretical framework for curriculum development in health professional education', Focus on Health Professional Education: A Multi-disciplinary Journal, vol. 14, no. 3, p. 70 .

Matveev, A.G., Veltri, N.F., Zapatero, E., Cuevas, N. 2010. 'Curriculum Mapping: A Conceptual Framework and Practical Illustration'. AMCIS 2010 Proceedings (Paper 515).

Mertens, D \& Wilson, AT. 2012. Program evaluation theory and practice: A comprehensive guide, Guilford Press, New York, NY.

Reid, A. 2005. 'Rethinking National Curriculum Collaboration. Towards an Australian Curriculum'. Department of Education, Science and Training, Canberra.

Muecke, MA. 1984. 'Community health diagnosis in nursing', Public Health Nursing, vol. 1, no. 1, pp. 23-35.

NANDA International. 2016. Glossary of Terms, NANDA International, viewed 1st July 2016, <http://www.nanda.org/ nanda-international-glossary-of-terms. htmls.

Riedford, KB. 2011. 'Bridging the gap between clinical experience and client access: Community engagement', Journal of Nursing Education, vol. 50, no. 6, pp. 337-40.

WHO 2008. The World Health Report 2008: Primary Health Care (Now More than Ever), World Health Organization, Geneva, Switzerland.

World Health Organization. 2009. Global standards for the initial education of professional nurses and midwives.

WHO 2010. 'A framework for community health nursing education', New Delhi: Regional office for South-East Asia of World Health Organization publishers, pp. 16-33.

WHO 2015. WHO Global Strategy on People-centred and Integrated Health Services: Interim Report, World Health Organization, Geneva, Switzerland.

WHO 2015. WHO Global Strategy on People-centred and Integrated Health Services: Interim Report, World Health Organization, Geneva, Switzerland. 